\title{
Urban Schools' Teachers Enacting Project-Based Science
}

\author{
Tali Tal, ${ }^{1}$ Joseph S. Krajcik, ${ }^{2}$ Phyllis C. Blumenfeld ${ }^{2}$ \\ ${ }^{1}$ Department of Education in Technology and Science, Technion, \\ Israel Institute of Technology, Haifa, 32000 Israel \\ ${ }^{2}$ University of Michigan, 610 East University, Ann Arbor, Michigan 42109
}

Received 16 July 2003; Accepted 20 April 2005

\begin{abstract}
What teaching practices foster inquiry and promote students to learn challenging subject matter in urban schools? Inquiry-based instruction and successful inquiry learning and teaching in projectbased science (PBS) were described in previous studies (Brown \& Campione, 1990; Crawford, 1999; Krajcik, Blumenfeld, Marx, Bass, \& Fredricks, 1998; Krajcik, Blumenfeld, Marx, \& Solloway, 1994; Minstrell \& van Zee, 2000). In this article, we describe the characteristics of inquiry teaching practices that promote student learning in urban schools. Teaching is a major factor that affects both achievement of and attitude of students toward science (Tamir, 1998). Our involvement in reform in a large urban district includes the development of suitable learning materials and providing continuous and practiced-based professional development (Fishman \& Davis, in press; van Es, Reiser, Matese, \& Gomez, 2002). Urban schools face particular challenges when enacting inquiry-based teaching practices like those espoused in PBS. In this article, we describe two case studies of urban teachers whose students achieved high gains on pre- and posttests and who demonstrated a great deal of preparedness and commitment to their students. Teachers' attempts to help their students to perform well are described and analyzed. The teachers we discuss work in a school district that strives to bring about reform in mathematics and science through systemic reform. The Center for Learning Technologies in Urban Schools (LeTUS) collaborates with the Detroit Public Schools to bring about reform in middle-school science. Through this collaboration, diverse populations of urban-school students learn science through inquiry-oriented projects and the use of various educational learning technologies. For inquiry-based science to succeed in urban schools, teachers must play an important role in enacting the curriculum while addressing the unique needs of students. The aim of this article is to describe patterns of good science teaching in urban school. () 2006 Wiley Periodicals, Inc. J Res Sci Teach 43: 722-745, 2006
\end{abstract}

\footnotetext{
Contract grant sponsor: NSF; Contract grant numbers: REC 0830310 A605, ESR-9908234, ESI-0227557.

Correspondence to: T. Tal; E-mail: rtal@tx.technion.ac.il

DOI 10.1002/tea.20102

Published online 1 May 2006 in Wiley InterScience (www.interscience.wiley.com).
} 


\section{Background}

The theoretical framework for this study encompasses three main fields in science education: the characteristics and challenges of teaching in urban schools, learning environments that encourage high-quality science teaching and learning, and high-quality teaching. We believe that only a systemic approach (Blumenfeld, Fishman, Krajcik, Marx, \& Solloway, 2000; Bybee, 1993) that addresses these issues will provide a coherent framework for discussing quality science teaching in urban settings. The literature that describes systemic reform often discusses issues of desired teaching methods and teachers' attitudes as strongly affecting science education in systemic initiatives (Kahle, 1997; Kahle, Meece, \& Scantlebury, 2000). The project-based science (PBS) approach that underlies our effort combines relevant topics, innovative teaching approaches that encourage active learning, and the construction of ideas. This approach has the potential to address many of the challenges urban schools face (Blumenfeld et al., 2000; Marx et al., 2004).

\section{Urban Schools}

Urban public schools in the United States face a variety of challenges while they struggle to provide positive and encouraging learning environments. Tobin, Roth, and Zimmerman (2001) warned that we are still in the midst of a crisis as urban schools in the United States continue to face many obstacles in meeting the needs of an increasingly diverse student population. Teachers and students work under stressful conditions and often experience alienation from the system and the community in which the school resides. Students have high rates of absenteeism and high mobility within the district. Students score low on standardized tests, and teachers are often underprepared (Hewson, Kahle, Scantlebury, \& Davies, 2001; Tobin, Seiler, \& Walls, 1999). Over crowded classrooms, old buildings, lack of resources, and infrastructure to support innovative teaching practices also plague urban districts (Barton, 1998; Kahle et al., 2000; Lynch, 2000). To deal with large classes and little equipment, many urban teachers use whole class instructional techniques in which students are passive learners. Haberman (1991) characterized this type of instruction as the pedagogy of poverty.

Urban schools use systemic reform as a model to create learning environments that promote all students in acquiring positive attitudes, knowledge, and skills (Anderson, 2001; Keys \& Bryan, 2001). Professional development targeted at improving the content knowledge and pedagogical skills of teachers, coupled with understanding science education reform and what it means for urban children, are necessary components for improving the teaching and learning in urban schools (Fishman, Marx, Best, \& Tal, 2003; Kahle et al., 2000; Lynch, 2000). Currently, textbooks and related materials serve as a major device for student to learn science; however, because of their inadequate design, these materials contribute very little to students' learning in general, and particularly do a disservice to students who have learning difficulties (American Association for the Advancement of Science, 2000; Kesidou \& Roseman, 2002; Stern \& Roseman, 2000). Moreover, traditional standardized assessment contributes very little to improve students' learning as well (Rodriguez, 2001).

Haberman (1991) described good teaching practice for urban schools which, he claimed, promotes learning for all students. Unlike the "pedagogy of poverty," good teaching occurs if students:

- solve problems that are of interest to them;

- explain human differences, see major concepts, big ideas, and general principles rather than accumulate isolated facts; 
- plan what they will be doing;

- apply ideals such as fairness, equity, or justice;

- do experiments and construct things;

- reflect on real-life experiences;

- work in heterogeneous groups;

- think about an idea in a way that questions common sense or widely accepted assumption;

- relate new ideas to ones learned previously or that apply an idea to the problems of living;

- redo, polish, or perfect their own works;

- access information through technology; and

- reflect on their own lives and how they come to believe and feel as they do.

Lynch and colleagues (1996) called for systematic development of science curricula with accompanying learning technologies to support learning and eliminate inequities in science classrooms. This position is supported by Tate (2001), who claimed that the role of technology is vital to the opportunity students have to learn science, and by Atwater (2000), who described "real-life experiences" of urban children and claimed that they have already formed ideas about natural phenomena and developed cognitive structures on which to hang new science ideas. Therefore, she suggested that using engaging curriculum materials, computers, and Internet access along with standards-based curriculum materials may help African American students to narrow the achievement and attitude gaps. Based on a synthesis of the literature, Blumenfeld et al. (2000) suggested that developing relevant standard-based curriculum, incorporating technology tools, and providing practice-based professional development might bring about changes when scaled throughout a large urban district.

\section{Curriculum and PBS}

The Center for Learning Technologies in Urban Schools (LeTUS) accepted the challenge put forth by Atwater (2000), Lynch et al. (1996) and Haberman (1991) to develop engaging curricula and the use of technology. The curriculum materials address everyday life, deal with real-life settings, and use technology to support inquiry and collaborative work. As part of our development efforts, we address Haberman's and Atwater's concerns by developing curricula materials according to PBS design principles (Blumenfeld, Marx, Patrick, \& Krajcik, 1998; Krajcik, Blumenfeld, Marx, Bass, \& Fredricks, 1998; Singer, Marx, Krajcik, \& Clay Chambers, 2000).

The design principles of PBS include a context that engages students in extended authentic investigations through a driving question, collaborative work that allows students to communicate their ideas, learning technologies to find and communicate solutions, and the creation of artifacts that demonstrate student understanding and serve as the basis for discussion, feedback, and revision (Krajcik, Blumenfeld, Marx, \& Solloway, 1994; Marx, Blumenfeld, Krajcik, \& Soloway, 1998; Singer et al., 2000). A driving question links concepts and principles, and drives activities and investigations throughout a project. Projects extend student learning experiences beyond the classroom by posing driving questions that situate the science with issues that are likely to be of interest to scientists, community-based organizations, and families. Anchoring events provide students with common experiences that help them see the value and purpose of the driving question. Anchoring experiences also help students relate to the new ideas explored in the project. Through teacher support, students design and perform various investigations to find solutions to the driving questions.

The projects we designed foster student collaboration within a learning community. Students communicate with each other, with teachers, and occasionally with community members and 
scientists to find information and solutions to their questions as well as to discuss their findings and understandings. Collaboration during investigations involves students interacting with peers in small groups or as part of large class discussions.

Learning technologies help students with the collection, analysis, and visualization of data. These tools also provide an environment in which students can construct artifacts and discuss their emerging understanding of concepts and processes related to the driving question. Artifacts represent students' problem-solving solutions that reflect emergent states of knowledge. Because artifacts are concrete and explicit (e.g., models, reports, videotapes, and computer programs), they can be shared and critiqued (Blumenfeld, Marx, Patrick, Soloway, \& Krajcik, 1997). Teachers may require students to explain how their artifact relates to the driving question or subquestion or represents a specific concept.

\section{Teaching and Teachers}

Although reform efforts envision thoughtful and demanding instruction, most instructional practice in the United States in general and in urban schools in particular is traditional with lecturelike, formal recitation as the common teaching strategy (Cohen \& Spillane, 1993; Haberman, 1991). The climate in most city schools is unrelieved negative. Teachers are tired, and many feel defeated. Weiner (1999) described situations in which teachers claim that their students cannot learn what is expected from them while other teachers in the same schools succeed in doing what others would consider impossible. Lynch (2000) argued that "schools with high number of students of color and low SES students are taught by less qualified teachers" (p. 138). Based on National Science Foundation and U.S. Department of Education reports, she claimed that the poorer the school, the higher concentration of inexperienced teachers. This situation is partially explained by the high turnover rate of teachers. Lynch also claimed that many teachers in urban schools are less qualified and occasionally lack the positive attitude toward their students or what she calls: "rapport and trust" (pp. 197-198) as suburban teachers.

Teachers' content knowledge and pedagogical skills are necessary, but not sufficient for science education reform. According to Putnam and Borko (1997), teachers require changes in their knowledge, beliefs, and practice to achieve goals such as helping students to construct understanding, develop expertise, and encourage the use of higher cognitive skills. This effort is not just a case of learning new strategies or techniques, but changing the overall perception of teaching and acquiring a new set of beliefs that direct future practice.

Various reform efforts (Edelson, 2001; Kahle et al., 2000; Krajcik et al., 1998; O’Day \& Smith, 1993; van Driel, Beijaard, \& Verloop, 2001) presented programs that include both curriculum development and teacher professional development. Our current effort in Detroit involves working on multiple fronts: curriculum, professional development, policy, infrastructure, and assessment (Blumenfeld et al., 2000). Such a diversified effort, we hope, will cause an increase in overall student achievement.

In our professional-development efforts, teachers are expected to understand and focus on the central ideas by suggesting and applying various adaptations to the relevant settings. Teachers play a major role in enacting the intended curriculum and adopting the centrality of inquiry and active construction of knowledge. They assign the time students spend on task, present the ideas, and build relationships. PBS encourages teachers to press students for understanding, foster students' reasoning, and diagnose misconceptions (Blumenfeld, 1992). Teachers' content knowledge and pedagogical content knowledge (PCK) play a major role in the way any curriculum, and especially an innovative reform-based curriculum, is enacted (Lynch, 2000; Magnusson, Krajcik, \& Borko, 1999; Putnam \& Borko, 1997). 
For students to achieve, they need appropriate opportunities to learn. Opportunity to learn (OTL) was first introduced several decades ago and was defined by a narrow set of instructional components emphasizing the amount of time students have on learning tasks. Since then, educators and policy makers have incorporated additional criteria into the OTL concept such as quality of teaching, type of assessment, and technology use (Schwartz, 1995; Tamir, 1998; Tate, 2001). According to Tamir (1998), one of the major reasons for unsuccessful curriculum innovations is the failure of implementing the innovations in a manner that matches what was intended. Teachers often teach in their traditional manner, but with new text. Tate (2001) claimed that the appropriate management of time, quality teaching, and the use of technology is central for the improvement of urban science education.

Based on Schwartz (1995), Stevens (1996), and Tate (2001), we suggest the following OTL variables as important for successful teaching.

\section{Content}

- Coverage: whether students cover the core curriculum and whether the curriculum taught aligns with the forms of assessment.

- Exposure: the time allocated to students to learn (time on task) and the depth of teaching the subject.

- Emphasis: which topics within the curriculum teachers emphasize, and whether teachers choose to teach for lower or higher order skills.

Time

- Whether or not teachers spend adequate time covering the content.

- Time students have to learn content on their own.

- The emphasis teachers place on important topics by assigning more class time for them.

\section{Teacher Competence}

- Whether teachers master course content and techniques to teach meaningfully, with particular attention to learning goals.

- Whether teachers use strategies for reaching diverse students with different learning styles.

Technology Use

- Whether and how technology use supports students' understanding.

\section{Measures of Good Teaching}

Putnam and Borko (1997) argued that reform efforts depend on teachers' ability to depart significantly from much of the practice that is based on views of teaching as presenting and explaining content, and learning as a rehearsal and retention of presented information and skills. They claimed that both curriculum and teaching help students build nascent understanding. Teachers, like students, interpret experiences through the filters of their existing knowledge and 
beliefs, which can be presented as pedagogical knowledge and beliefs, subject-matter knowledge and beliefs, and PCK and beliefs. Pedagogical knowledge includes teacher's knowledge and beliefs about teaching, learning, and learners, not specific to particular subject matter (Putnam \& Borko, 1997). Conceptions of learning such as active construction, learning in social context, and teachers as mediators (Blumenfeld et al., 1997) are all aspects of pedagogical knowledge and beliefs. Content or subject-matter knowledge affects the learning experiences that teachers provide to their students. Teachers with deeper understanding of subject matter tend to emphasize conceptual, problem-solving, and inquiry aspects of their subjects whereas less knowledgeable teachers tend to emphasize facts and procedures (Ball, 2000; Cochran \& Jones, 1998; Kahle et al., 2000; Putnam \& Borko, 1997). PCK refers to the "ways of representing and formulating the subject that make it comprehensible to others" and "an understanding of what makes the learning of specific topics easy or difficult: the conceptions and the preconceptions that students of different ages and backgrounds bring with them to the learning of those most frequently taught topics and lessons" (Shulman, 1986, p. 9). In more recent works, Cochran and Jones (1998) described PCK as an integrated component of knowledge of pedagogy, content, learning, and students.

Another important measure, especially in urban schools, is the level of commitment and involvement of the teacher in the reform objectives and efforts. Such commitment is often expressed by a teacher's attitude toward students. According to Lynch (2000) and Tobin et al. (2001), a teacher's commitment and desire for students to succeed will have an effect on student achievement.

In light of all the factors associated with systemic reform, complex relationships exist among design of curriculum materials, teaching, learning, and professional-development programs as well as resources, policy, and infrastructure (Blumenfeld et al., 2000). Because PBS involves design cycles of revision and enactment and demands high-quality teaching, the goal of this study was to describe various measures of teaching that can explain students' achievements. Our question was: "What teaching practices foster inquiry and promote students' learning of science in urban schools?" Our goal was not to compare the teachers but rather to describe good teaching practices that foster students' learning. Defining these measures and checking them against achievements allows us to describe patterns of teaching and highlight the knowledge domains that should be the focus of our future professional development.

Several studies describing middle-school teachers involved in inquiry-based science (Krajcik \& Starr, 2001; Ladewski, Krajcik, \& Harvey, 1994; Marx et al., 1994; Novak \& Gleason, 2001) have shown a strong connection between good implementation and understanding of the basic ideas of the reform in science education. Teachers who carry out PBS curriculum struggle with various issues such as technology use and collaboration; however, urban teachers who enact PBS face more severe challenges.

In this article, we present 2 teachers who succeeded in enacting PBS curriculum in urban middle schools in a large school district. The students of these teachers showed higher gains on posttest assessments compared to students of other teachers using this curriculum.

\section{Settings and Methods}

University of Michigan (UM) scientists and educational researchers and Detroit Public Schools (DPS) have worked together to reform science education for middle-school students (Blumenfeld et al., 2000). DPS, a large system, serves about 165,000 students from a diverse urban community and employs about 10,000 teachers and other education professionals. Many students come from poor families, with about half of Detroit's children and youth living in families who are at or below the poverty line, are largely minority, and tend to be mobile. Dropout rates in the DPS 
are high, and students' standardized test scores are low compared with performance of students across the State of Michigan. Like many urban systems, frequent changes occur in leadership. Across the district, 91\% of the students are African American, 4\% are Latino, 4\% are White, and $1 \%$ is Asian. The schools in this study are representative of this distribution. Because of mutually agreed upon procedures established with the school district, we do not report data based on the racial or ethnic identities of the students.

The collaborative work between DPS and UM took place within curriculum projects funded by the National Science Foundation: the Detroit Urban Systemic Program and the Center for Learning Technologies in Urban Schools (LeTUS). This collaboration saw its core challenge as the infusion of learning technologies to support learning via inquiry in urban classrooms. The participating schools were equipped with several computers in each science class and were occasionally supported by the university staff who helped mainly in the initial steps of technology implementation.

The collaboration also provided a professional-development program that included summer institutes, Saturday workshops, classroom support, and after-school work sessions. During summer institutes, teachers learned about the various curricula (i.e., projects), experienced project-based learning activities, used technology related to the various inquiry activities, and collaborated with each other and with the university staff in small-group discussions on issues related to enactment. Saturday workshops, held during the teaching process, allowed teachers to experience the learning activities and discuss students' difficulties and misconceptions based on their classroom experience, artifacts, and assessments (Fishman et al., 2003). After-school work sessions were held by the teachers and allowed them to share knowledge and experiences regarding the sequence of teaching. Often during classroom support, experienced teachers, including those from DPS and UM, model taught portion of lessons and coached classroom teachers on how to do inquiry and use technology.

The teachers described in this study taught the seventh-grade air-quality project, an eighthgrade force and motion project, and a seventh- or eighth-grade water-quality project. Each project encompassed 8 to 12 weeks of instruction. The projects were enacted in the 1998-1999 and 19992000 academic years to over 700 students in 1998 and about 1,500 students in 1999. Almost all the participant students were African American.

\section{Method}

This qualitative interpretative study (Gallagher, 1991; Patton, 1990; Schwandt, 1994) focused on two Detroit teachers: Ms. Anderson and Ms. McGee. Qualitative methods permit the researcher to study selected issues or cases in depth and in detail (Patton, 1990). We purposefully selected the cases of Ms. Anderson and Ms. McGee from the enactment of approximately 25 teachers who participated during the 1998-1999 and 1999-2000 school years. We had detailed video data of 10 teachers; however, we selected these 2 teachers to represent effective teaching practices, various idiosyncratic challenges teachers in urban schools face, and practices used by the teachers that led their students to succeed and present relatively high achievements.

The logic and power of purposeful sampling lies in selecting information-rich cases for study in depth. Information rich cases are those that from which one can learn a great deal about issues of central importance to the purpose of the research, thus the term purposeful sampling. (Patton, 1990, p. 169)

The approach of selecting "best cases" is based, as well, on St. John and Pratt (1997), who studied common features of best cases in standard-based reform. They claimed that a collection of 
such cases enables extracting the most contributory factors in the reform. Best cases of art and music teachers have yielded a rich portrait that captures how these teachers manage to teach in effective ways despite their workplace constraints, and what students can learn given their teachers' subject-matter knowledge and their pedagogical expertise (May, Lantz, \& Rackliffe, 1993).

Our goal was to present exemplary cases of good teaching practices and not to compare these cases, or to compare them with cases of poor teaching. Based on the initial criteria for OTL, the university staff who followed all the teachers nominated these 2 teachers to represent the higher range of teacher performance because they covered the major components of the curriculum, presented reasonable content knowledge, used good management skills, and addressed the diverse population of their classes.

\section{Participants}

Ms. Anderson has 6 years of teaching experience, all in science. She has a B.A. in Education and Social Science and minors in Science and Language Arts. She holds certifications in K-5 (all subjects) and 6-8 (social science, science, and language arts). She taught in a normal, typical neighborhood middle school in Detroit. The students who Ms. Anderson taught come from the nearby area. The school had a population of $97 \%$ African American, and over $70 \%$ of the students participated in the free or reduced lunch program. Ms. Anderson enacted the "What affects the air quality in my community?" project, which is described in detail in the fore, in Fall 1998 and in Fall 1999, and the "What is the water like in our river?" project in Spring 1999 and in Spring 2000. We report on the enactment of the air quality project.

Ms. McGee taught for 19 years, all in science. She has an undergraduate major in General Science with a minor in Social Science and a M.A. in Science Education, with certificates in elementary education and endorsements in all subjects $\mathrm{K}-8$. Ms. McGee taught in a magnet school. Students applied for admission; however, admission did not depend on achievement tests or ability but rather on the child's and parent's commitment to attend the school. The socioeconomic status of the parents of these students who attend Ms. McGee's school is similar to Ms. Anderson's school. The school had a population of over 90\% African American, and over 70\% of the students participated in the free or reduced lunch program. Ms. McGee enacted the "Why do I have to wear a helmet when I ride my bicycle?" project, which is described in detail in the fore, in Fall 1998, and the "What is the water like in our river?" in Spring 1999. We report on Ms. McGee's enactment of the force and motion project.

\section{Data Collection}

UM staff videotaped the classrooms across the projects approximately three times a week. Pre- and posttests were administered in all participating classrooms at the beginning and at the end of each project. Based on Taines, Schneider, and Blumenfeld (2000), we selected tapes from three continuous events in each curriculum: investigations, technology use, and artifact creation. The lessons selected varied to represent whole-group, small-group, and individual interactions and occurred in different parts of the unit (Blumenfeld, 1992; Krajcik et al., 1994; Taines et al., 2000). Approximately 15 lesson periods of videotapes per teacher were analyzed for this study. To assess student understanding of the curriculum content and science process skills, we developed written assessment instruments that were administered to each student participating in the curriculum projects. We present here students' scores for the three curriculum units described earlier. The assessments, which were developed by the curriculum developers and assessment experts, 
consisted of a combination of multiple-choice and free-response items that were further classified as either curriculum content knowledge or science process skill items. Content and process items were categorized into one of three cognitive levels: lower (recalling information; understanding simple and complex information); middle (drawing or understanding simple relationships; applying knowledge to new or different situations; shifting between representations such as verbal to graphic; scientific processes such as identifying hypotheses, procedures, results, or conclusions); and higher (describing or analyzing data from charts and graphs; framing hypotheses; drawing conclusions; defining or isolating variables given in a scenario; applying investigation skills; and using concepts to explain phenomena). Content validity was ensured by creating items based on a matrix of topics that reflected the relative importance of the content and processes in the curriculum materials. The detailed scoring system and examples for test items were presented by Marx et al. (2004). Teams of two to four raters analyzed the open-ended items and achieved $95 \%$ accuracy in categorizing items. Disagreements were settled by consensus (Marx et al., 2004).

\section{Data Analysis}

We selected the following units of analysis for this study: curriculum cover, time on task, accuracy of content knowledge, curriculum emphasis and thoughtfulness (PCK), use of technology, and collaboration and attitudes toward students (Blumenfeld, 1992; Magnusson et al., 1999; Putnam \& Borko, 1997; Schwartz, 1995; Stevens, 1996; Tate, 2001).

Table 1 presents these analysis criteria and short description of each. Data were analyzed in several stages. First, a detailed summary of each videotape was prepared. This summary included description of the teacher's and students' actions and conversations. Then, instances of the teacher initiating lessons, whole-class discussion, and summarizing and concluding lessons were coded for curriculum coverage, scientific accuracy, curriculum emphasis, collaboration, and attitude toward the students. The last step involved synthesizing across classrooms and teachers to form a general coherent description of good teaching in urban schools.

To describe the range of performances, we used the following classifications scheme: (a) thorough, skillful, and excellent to describe the highest level of teaching performance; (b) sufficient and adequate to indicate when the performance was good enough; and (c) fair to describe mediocre performance.

Member checking, a common procedure that enhances the research validity in qualitative research (Guba \& Lincoln, 1985; Janesick, 2000), was achieved in two ways: (a) The 2 participating teachers were requested to read the manuscript and to make comments; and (b) discussions between the first and coauthors and other colleagues who know the setting and the teachers highlighted issues for reexamination and further data analysis to support our claims. The teachers made only minor comments that were later addressed by the authors and incorporated into the document.

\section{Findings}

In describing Ms. Anderson and Ms. McGee, we did not aim to present the ideal teacher who represents the highest possible teaching skills. We claim that within the urban schools we observed and were involved with, these 2 teachers expressed many characteristics of effective teaching. Each teacher had strengths and experienced challenges in her teaching; however, their students did very well on the posttests, and our observations indicated that most of the criteria for good teaching in urban schools are presented in their work. As these teachers continued teaching, they continued to show improvements in their enactments. 
Table 1

Analysis scheme for coding the videotapes

\begin{tabular}{|c|c|}
\hline Analysis Criteria & Description \\
\hline Curriculum coverage & $\begin{array}{l}\text { The extent to which the curriculum events were covered, including if } \\
\text { the main activities were enacted and if the main concepts were } \\
\text { discussed in class. }\end{array}$ \\
\hline Time on task & $\begin{array}{l}\text { The time allocated to students to learn the main concepts and be } \\
\text { engaged in the investigations or other thinking activities in class. }\end{array}$ \\
\hline Accuracy (content knowledge) & $\begin{array}{l}\text { Whether the teacher is accurate in the use of scientific ideas and } \\
\text { concepts and the manner in which the teacher presents scientific } \\
\text { ideas. }\end{array}$ \\
\hline $\begin{array}{l}\text { Curriculum emphasis (pedagogical } \\
\text { content knowledge) }\end{array}$ & $\begin{array}{l}\text { Curriculum utilization by the teachers; the depth of teaching the } \\
\text { subject; press for understanding by questioning or help students } \\
\text { undercover the meaning of concepts; use of the driving question } \\
\text { and the contextualizing event throughout the unit; teacher's use } \\
\text { of analogies and metaphors; encouraging expressing higher order } \\
\text { thinking skills such as emphasis on getting evidence and drawing } \\
\text { conclusions; addressing students' misconception and using } \\
\text { them to improve learning. The way the teacher enacts the } \\
\text { investigations, does inquiry, and integrates the scientific concepts } \\
\text { to everyday experience. }\end{array}$ \\
\hline Technology use & $\begin{array}{l}\text { How often the teacher uses technology; the level of comfort the } \\
\text { teacher shows with using technology in the classroom. How the } \\
\text { teacher enacts the technology activities, and makes meaning by } \\
\text { connecting the technology activity to the main questions and } \\
\text { ideas in the project. }\end{array}$ \\
\hline Collaboration & $\begin{array}{l}\text { Whether the teacher allows/encourages the students to work in small } \\
\text { groups, encourages them to discuss and share their ideas and } \\
\text { present group work. }\end{array}$ \\
\hline Attitude toward the students & $\begin{array}{l}\text { The level of respect and empathy the teacher shows toward the } \\
\text { students. The level of desire the teacher demonstrates for the } \\
\text { students' success, the efforts the teacher shows in encouraging } \\
\text { the students to do their best. Whether the teacher promotes } \\
\text { independence and supports self-regulation. }\end{array}$ \\
\hline
\end{tabular}

\section{Ms. Anderson's Case}

Ms. Anderson's background was described in the participants section. She was documented teaching the "Air Quality" project that centered on the driving question "What is the quality of the air in my community?" and included the concepts of the particulate nature of matter, states of matter, and chemical change. The idea for that project came up from meeting of the UM staff, teachers and school staff, and the parents. During the project, students took a walk around the school to observe the effects of air pollution. This walk served as a contextualizing event throughout the project. Students performed group-inquiry activities such as measuring and calculating the percent of oxygen in the air and determining the effects of acid rain on the environment. Students used modeling software to create air quality models that could be tested and evaluated. The project concluded with students in small groups making extensive presentations comparing air pollution in two U.S. cities. Presentations provided students with the opportunity to demonstrate their knowledge on relating sources and effects of pollutants, the chemistry of air quality, and the states of matter. The case described here comes from Ms. Anderson's second year enacting the project. 
General Description. Ms. Anderson's class was very neat and well organized. She presented excellent management skills. She never raised her voice and always addressed her students with respect. She always came to class prepared and presented material in a structured manner. She began each class with the title of the lesson and the driving question written on the board with several questions for bell work posted. She also had a series of overheads ready for class. When the students entered the room, they immediately gathered their journals from marked plastic boxes and started their bell work. From that moment until the end of the class period, most students concentrated on their work, either in groups or as a whole- class activity, while Ms. Anderson walked among the groups and encouraged as many students as possible to participate.

Test Results. On the air and water curriculum projects from the 1999-2000 school year, Ms. Anderson's students demonstrated the highest gains compared with other teachers in the project. Tables 2 and 3 show Ms. Anderson's students' net gains compared with the average of the gains of other teachers' students. Ms. Anderson's effect size of 0.6 and 0.9 SDs higher than the average effect of 10 other teachers indicates that she does something different in her classes.

Performance Characteristics. Using the criteria in Table 1, we analyzed videotapes and field observations to describe Ms. Anderson's performance. In the following section, we discuss the characteristics of Ms. Anderson's teaching. Table 4 summarizes her performance.

Curriculum Coverage. Ms. Anderson demonstrated excellent curriculum coverage. She paced the class so that students completed all activities, including presentations that were time consuming and scheduled at the end of the curriculum. She also enacted computer-modeling activities that other teachers avoided in air curriculum. To introduce this modeling activity, she designed her own introduction activity in which the students suggested various factors and then drew them on paper before working with the computer program. She successfully completed an activity in which the students asked questions and collected data about pollution and pollutants in Detroit versus other major cities in the country, and allowed students to discuss findings. In discussions with UM staff, she always acknowledged the fact that the curriculum's length was appropriate.

Time on Task. Time on task means not only the time the teacher allocates to cover the main ideas but also whether the students have enough time to learn the ideas on their own, go over difficult ideas, and exercise skills. In general, Ms. Anderson gave feedback about previous activities and monitored completion and understanding at the beginning of each class period. She asked her students to report on their previous activity and to summarize what their groups have accomplished. Our video analysis shows that students usually completed work and quietly spoke

Table 2

Students' net gains in pre-posttest in 1999-2000 Air Quality curriculum

\begin{tabular}{lcccccc}
\hline 1999-2000 Air & $n$ & Max & Pre & Post & Average Gain & Effect Size \\
\hline Students of teachers 1-8 & 472 & 24 & $6.44(3.08)$ & $9.80(4.59)$ & $3.36(3.90)$ & $1.09^{* * *}$ \\
Ms. Anderson's students & 116 & 24 & $6.79(2.85)$ & $12.52(4.24)$ & $5.72(3.87)$ & $2.01^{* * * *}$ \\
Total & 588 & 24 & $6.51(3.04)$ & $10.33(4.65)$ & $3.82(4.00)$ & $1.26^{* * *}$ \\
\hline
\end{tabular}

**** $p<.01$. 
Table 3

Students' net gains in pre-posttest in 1999-2000 Water Quality curriculum

\begin{tabular}{lcccccc}
\hline 1999-2000 Water & $n$ & Max & Pre & Post & Average Gain & Effect Size \\
\hline Students of teachers 1-10 & 636 & 24 & $8.24(3.14)$ & $11.26(3.94)$ & $3.02(3.30)$ & $0.96^{* * *}$ \\
Ms. Anderson's students & 119 & 24 & $8.71(2.91)$ & $13.20(4.11)$ & $4.49(4.32)$ & $1.54^{* * * *}$ \\
Total & 755 & 24 & $8.31(3.11)$ & $11.56(4.03)$ & $3.25(3.51)$ & $1.05^{* * *}$ \\
\hline
\end{tabular}

${ }^{* *} p<0.1$.

**** $p<.05$.

until the teacher called for attention. While the students worked, Ms. Anderson quietly spoke with different groups and assessed and marked their journals. With regard to technology use, several students, due to personal differences, struggled with using the computers and exercising the mouse and keyboard. Although the software program enables middle-school learners to build dynamic

Table 4

Summary of Ms. Anderson's teaching practices

\begin{tabular}{|c|c|c|}
\hline Criteria & General Description & Evidence \\
\hline Curriculum coverage & Thorough & $\begin{array}{l}\text { Both videos and reports of support personnel indicate that } \\
\text { all the activities in the suggested sequence were } \\
\text { covered. The teacher paced her students and moved } \\
\text { them through the activities. She managed to complete } \\
\text { collecting data about the city's pollutants. }\end{array}$ \\
\hline Time on task & Adequate & $\begin{array}{l}\text { Teacher allocated time for all the activities, but often } \\
\text { it seems that students need more time for better } \\
\text { understanding. }\end{array}$ \\
\hline Content knowledge & Sufficient & $\begin{array}{l}\text { Most of our videos indicate that her content knowledge } \\
\text { was accurate; however, some inaccuracies were } \\
\text { observed. }\end{array}$ \\
\hline $\begin{array}{l}\text { Pedagogical content } \\
\text { knowledge }\end{array}$ & Adequate & $\begin{array}{l}\text { She used many analogies and repeated them. She } \\
\text { monitored students' learning. She enacted } \\
\text { investigations and integrated scientific concepts to } \\
\text { everyday experiences. She used the driving question } \\
\text { throughout the enactment, and referred to the } \\
\text { neighborhood walk (contextualizing event). } \\
\text { She modeled concepts and principles, and created } \\
\text { kinesthetic experiences to link body movements with } \\
\text { scientific phenomenon. } \\
\text { She did not, for her own explained reasons, press enough } \\
\text { for understanding; few attempts to foster higher order } \\
\text { thinking were observed. We saw only some attempts to } \\
\text { challenge misconception or use them to improve } \\
\text { learning. }\end{array}$ \\
\hline Technology & Skillful & $\begin{array}{l}\text { She used technology efficiency and appropriately. } \\
\text { She assisted the students, and enacted all the } \\
\text { technology-based activities. }\end{array}$ \\
\hline Collaboration & Fair & $\begin{array}{l}\text { Students did some group work, and reported to each } \\
\text { other, but they hardly discussed ideas, debated, or } \\
\text { presented controversies. }\end{array}$ \\
\hline $\begin{array}{l}\text { Attitude toward the } \\
\text { students }\end{array}$ & Excellent & $\begin{array}{l}\text { The teacher demonstrated high respect for her students in } \\
\text { the way she talked, guided, and expected students to } \\
\text { complete work. }\end{array}$ \\
\hline
\end{tabular}


computer-based models, represent variables and relationships, and observe how these variables affect each other (Jackson, Krajcik, \& Soloway, 2000), these students rarely had enough time to work with the program.

Content Knowledge. Ms. Anderson's students demonstrated sufficient content knowledge, although some inaccuracies were observed. Analysis of the videotapes showed that she understood the main scientific ideas of the curriculum. We observed a few attempts to simplify scientific ideas, which might cause misunderstandings in students. For instance, while discussing clean and polluted air, she implied that polluted air has less oxygen compared to clean air by asking: "Does polluted air have the same oxygen like clean air?" All the class replied "No." The fact that she accepted this answer might indicate that she had her own misunderstanding about the percentage of oxygen in polluted air; however, when a university support person discussed this confusion with Ms. Anderson, she corrected herself in class in the following period. In another example, the class role played CFC's in air. Ms. Anderson made students who were role playing CFC's molecules chase and catch the students who were playing oxygen molecules; however, CFC molecules randomly meet oxygen molecules. Regardless of these inaccuracies, Ms. Anderson demonstrated good understanding of the content. She frequently allowed university support personnel in her class and was always very willing to discuss the curriculum contents and her enactment.

$P C K$. Ms. Anderson also demonstrated her understanding of the content and how to present it to children by creating and using original and appropriate representations of content, representing one aspect of PCK. For instance, after drawing how solid, liquid, and gas particles would behave, she requested that the whole class demonstrate how matters in the various phases behave by moving their fingers and hands. When Ms. Anderson said solid, students held their hands tightly. To show a liquid, students moved their fingers gently to mimic the movement of liquid molecules. For a gas, students moved fingers and shook hands fast to demonstrate the movement of molecules or elements in the gases phase. Most students correctly used their hands to do these physical representations. Then, she put a clear box on the overhead. The clear box was made of a wood frame, covered by transparencies with wood pieces inside. Through projection, students could see shadows of wood pieces on the screen. She then shook the box to make the pieces very close to each other and asked students what phase of matter these pieces represented. Some students answered "a solid." The teacher kept shaking the box to make pieces far apart, and students responded "liquid." Finally, the wood pieces moved faster and scattered in the whole box, and students answered "a gas."

To summarize what the class just modeled and to introduce a new concept, Ms. Anderson encouraged the students to think about and recall how they refer to a solid changing to a liquid in their daily life. Several students answered "melting." She then confirmed the answer and showed a transparency with equationlike and visual representations of a liquid and a solid. The class went through sublimation, precipitation, condensation, and evaporation. She explained each process/ concept using verbal and visual representations, and concluded by asking students in each group to choose a phase-changing process and to use the hand representation to demonstrate the process. By going back to various phases of precipitation, Ms. Anderson connected the scientific concepts to everyday experiences.

Ms. Anderson used a variety of models and representations to help students learn the concept of phase changes. During this 25-min event, students repeatedly experienced the ideas of molecules, phases, movement, energy, and models and learned to use models to represent invisible 
particles (Singer, Tal, \& Wu, 2003). Additionally, the teacher brought in an example of soda and asked students to apply their model to make explanations about the liquid they see and about the gas bubbles. This scenario reveals that Ms. Anderson used various representations as resources to help middle-school students learn challenging science content.

Ms. Anderson, however, did not use students' mistakes as an opportunity to learn. When students made mistakes, she rarely prompted them for further clarification or used their comments as a trigger for class discussion. One explanation for this is that she had insufficient PCK to make use of the students' inaccurate responses; however, from informal conversation with Ms. Anderson, we learned that she purposely did it because she avoids pointing out students' errors in class for fear that students might be embarrassed and subsequently decide not to take part in classroom discussions. The following excerpt from a discussion on air pollutants illustrates this point.

Student: the hydrogen part of $\mathrm{H}_{2} \mathrm{O}_{2}$.

Teacher: This is a liquid, so what makes you say it pollutes?

Student: the hydrogen.

Teacher: This is interesting.

At this point, the discussion ended. Ms. Anderson went on to discuss other ideas and never discussed the difference between hydrogen gas and hydrogen in a compound or the issue of hydrogen as a pollutant. Her reluctance to point out errors showed in other ways as well. Many times, she used class votes as a means for choosing the right answer. Another common practice was asking various students until she got the correct response.

One indication that Ms. Anderson might have had insufficient content understanding in some areas is that at times she used generic definitions rather than helping students fully understand an idea. For instance, she used a demonstration of burning "flash" paper to illustrate a chemical change. She then provided only this definition: "Chemical changes produce something new, and you cannot get the original substance back. A physical change it's still the same substance." The last example illustrates the teacher avoiding a very important scientific idea, and not going into depth to help her students understand; however, it is important to realize that the materials that Ms. Anderson used also did not provide an in-depth explanation.

Technology Use. With respect to technology use, Ms. Anderson always had the computers in her room ready to use, and she was very proficient in using them. Moreover, she connected the technology-based activities to previous experiences. For instance, when the students used chemistry modeling software that allowed them to make representations of molecules, she linked this activity to a previous gumdrop model activity. While using the modeling software program, she asked the students to refer back to relationships they drew in a prior paper and pencil activity. However, in several of the videotapes we analyzed, she tended to be procedural, probably because of time constrains. She barely checked or asked students to explain the relationships they created while engaged in the computer-based modeling activity. It also was one of the first times she used the program, and she might have been trying to determine herself how to best use it in her classroom. We know from subsequent conversation and observations that Ms. Anderson will try out new ideas and become more adventuresome as she gains classroom experience. Nevertheless, she was proficient with facilitating technology activities in her class; therefore, we described her as skillful, recognizing that there are areas where she can improve. 
Collaboration. Both classroom videos and interviews with target students indicated that small-group work occurred in Ms. Anderson's class. Ms. Anderson requested that the students report to each other and come to a group agreement. She frequently asked students to complete their own work and only then to share their answers; however, we scarcely observed debates or deep discussions in groups. In the interviews, most students regarded the question and answer pattern as "discussions." In informal talks with Ms. Anderson, she expressed that she needed to encourage more collaboration in her class.

Attitudes. All classroom videos and classroom observations illustrated a very calm and caring atmosphere in class. Ms. Anderson worked at creating this atmosphere. She emphasized her expectation for the students to do their best. For instance, Ms. Anderson used a short poem about "doing the best we can" that she and the students repeated daily when they started class. On a few occasions, she told the students how important they are to their parents, and how the parents would like them to succeed. Therefore, they have to work very hard in school. Ms. Anderson also never shouted or expressed frustration, and if she had to discuss personal issues, she called the student to her desk. Finally, as we pointed out previously, Ms. Anderson never criticized students in class, and it was obvious that the students highly respected her.

\section{Ms. McGee's Case}

Ms. McGee was documented teaching the "Force and Motion" project that centered around the driving question "Why do I need to wear a helmet when I ride my bike?" to explore the concepts of motion, force, velocity, and acceleration. The relevant context for this project was accidents and public safety while driving and riding in the city. Students planned and designed experiments, and collected and analyzed data using motion sensors with a computer interface to examine distance-time, velocity, and acceleration graphs to support their inquiry into the driving question. The anchor for the project was a series of egg-and-cart demonstrations in which an egg represented a student and the cart represented a bike. In these demonstrations, Newton's first laws of motion, force, mass, velocity, and acceleration could be related. The project concluded with students working together to design helmets for their eggs and crash-testing them. Students used motion sensors to describe the motion of the carts and eggs to demonstrate the importance of wearing a helmet when they ride their bikes. Their helmet artifact was part of a final presentation in which groups of students presented data they collected, interpreted, and shared with their classmates. The case described here is from Ms. McGee's first year on the project.

General Description. Ms. McGee welcomed her students with a smile when they entered the class. She tried to create an informal atmosphere, and sometimes it took a few moments until the class actually started. Ms. McGee always came to class prepared. She had activities and student worksheets ready. Ms. McGee planned her lessons thoroughly as evidenced by her curriculum materials that looked very worn out. She had dozens of colored stickers between the pages, which indicated that she read, planned, and used the materials.

Test Results. On the force and motion (physics) curriculum of 1998-1999, Ms. McGee's students showed the highest gains. Unfortunately, her students did not take the water pretests that year; however, they demonstrated the highest posttest scores, which were significantly higher than the students of the other teachers in all test categories. Table 5 shows Ms. McGee's students' net gains from the force and motion unit compared with the average from students in other teachers 
Table 5

Students' net gains in pre-posttest in 1998-1999 Force and Motion curriculum

\begin{tabular}{lcccccc}
\hline 1998-1999 Physics & $n$ & Max & Pre $(S D)$ & Post $(S D)$ & Average Gain & Effect Size \\
\hline Students of teachers 1-3 & 49 & 53 & $11.67(4.10)$ & $14.41(5.51)$ & $2.73(4.01)$ & $0.67^{* * *}$ \\
Ms. McGee's students & 29 & 53 & $16.03(3.45)$ & $23.59(6.16)$ & $7.55(5.09)$ & $2.19^{* * * *}$ \\
Total & 78 & 53 & $13.29(4.39)$ & $17.82(7.26)$ & $4.53(5.00)$ & $1.03^{* * * *}$ \\
\hline
\end{tabular}

${ }^{* *} p<0.1$.

**** $p<.05$.

classrooms. Her effect size was 1.5 SDs higher than students from other teachers. Table 6 shows the high water posttest scores. These results indicate that students in Ms. McGee's class learned ideas from the curriculum materials.

Performance Characteristics. As in the case of Ms. Anderson, we used the criteria in Table 1 analyze classroom videotapes and field observations to describe Ms. McGee's performance. In the following section, we discuss the characteristics of her teaching, and Table 7 summarizes her performance.

Curriculum Coverage. Ms. McGee managed to cover the entire curriculum and to do all the activities. Ms. McGee gave additional time to students to struggle with activities or to make their reports. Although students were engaged in doing investigations, she kept sending them back to write up their reasons, to discuss again in their groups, and to come up with conclusions. A few videos showed the teacher encouraging debates and allowing students to critique and suggest other ideas.

Time on Task. Once Ms. McGee settled the class, the remaining time was dedicated for working on the project tasks. She was well prepared for every task. During class, the students were engaged doing their investigations.

Content Knowledge. Ms. McGee's content knowledge was excellent. She emphasized important concepts, and we did not observe any situation in which she presented misinformation. Sometimes during class discussions, she appeared puzzled for a second, but then she organized her thoughts and discussed the ideas again with the students.

$P C K$. One of the indicators of high-quality PCK is a teacher's press for understanding and cognitive engagement (Blumenfeld, 1992; Blumenfeld et al., 1997). A teacher presses for understanding by focusing students' attention by encouraging them to think about and examine

Table 6

Average posttest scores in 1998-1999 Water Quality curriculum

\begin{tabular}{lrccc}
\hline 1998-1999 Water & $n$ & Max & Posttest Mean (SD) & \multicolumn{1}{c}{$S E$} \\
\hline Students of teachers 1-5 & 345 & 33 & $9.90(5.01)$ & 0.270 \\
Ms. McGee's students & 27 & 33 & $17.07(5.57)$ & 1.071 \\
Total & 372 & 33 & $10.42(5.38)$ & 0.279 \\
\hline
\end{tabular}


Table 7

Summary of Ms. McGee's teaching practices

\begin{tabular}{|c|c|c|}
\hline Criteria & General Description & Evidence \\
\hline Curriculum coverage & Thorough & $\begin{array}{l}\text { Both videos and reports of support personnel indicate that } \\
\text { all activities were covered according to the suggested } \\
\text { sequence. }\end{array}$ \\
\hline Time on task & Thorough & $\begin{array}{l}\text { She allocated time for all activities. On few occasions, } \\
\text { she decided to give more time for students to struggle } \\
\text { with activities or making their reports. }\end{array}$ \\
\hline Content knowledge & Excellent & $\begin{array}{l}\text { Our videos indicate that she thoroughly understood the } \\
\text { content of the curriculum. }\end{array}$ \\
\hline $\begin{array}{l}\text { Pedagogical content } \\
\text { knowledge }\end{array}$ & Excellent & $\begin{array}{l}\text { She pressed students for understanding throughout the } \\
\text { curriculum. She used the driving question and the } \\
\text { contextualizing event throughout her teaching. She } \\
\text { asked numerous questions and she rarely told students } \\
\text { answers. }\end{array}$ \\
\hline Technology & Skillful & $\begin{array}{l}\text { She used technology efficiently and appropriately. She } \\
\text { assisted the students, and enacted all technology-based } \\
\text { activities. }\end{array}$ \\
\hline Collaboration & Excellent & $\begin{array}{l}\text { She encouraged students to share and develop ideas and } \\
\text { demanded that they discuss everything in groups. }\end{array}$ \\
\hline $\begin{array}{l}\text { Attitude toward the } \\
\text { students }\end{array}$ & Excellent & $\begin{array}{l}\text { The teacher demonstrated respect for her students in the } \\
\text { way she talked, guided, and expected work to be done. }\end{array}$ \\
\hline
\end{tabular}

ideas instead of getting the right answers. Teachers press for understanding by using questions, activities, analogies, and metaphors to help the students undercover the meaning of concepts. We added this category here because it was clear that Ms. McGee pressed her students for understanding. We observed Ms. McGee doing so throughout the curriculum enactment, and we have many examples that serve as evidence. Throughout the unit, she went back to the driving question and the contextualizing event. She asked students to provide reasons, explanations, and evidence for what they did and observed in the investigations. She encouraged them to critique each other and herself. She also kept linking the force and motion ideas to real-life phenomena such as riding bike or going on a roller coaster. In one example, when the students had difficulty with understanding velocity and acceleration graphs, she told them not to ask her.

I want you to begin to understand the graphs. Look at the meter per seconds on the graph. Read the numbers. It will tell you what the velocity or acceleration was. Then you can compare to the next set of trials.

Then she checked on the different groups. It was clear that Ms. McGee did not try to provide answers to her students' questions but rather preferred to probe until the student understood. She did not mind when students of different groups shared their knowledge, and often we observed how she helped one group to understand a graph and then let those students explain the graph to another group. Ms. McGee also made students rewrite their conclusions, and at the end of many activities, students reported to the class. Ms. McGee did not use as many analogies and models but did encourage her students to share and develop ideas.

Technology. The force and motion curriculum offered many opportunities to use technology tools, and Ms. McGee was skillful with facilitating the investigations. She noticed when students struggled with motion detectors or with understanding the graphs. She moved between the groups 
and helped the students. Ms. McGee appeared to easily facilitate the transition between students using computers and students engaging in classroom discussions.

Collaboration. As mentioned earlier, Ms. McGee encouraged her students to share and develop ideas. She also demanded that they discuss everything in groups. The classroom videos showed that students felt comfortable doing group work. Although the class often was noisy, it was productive noise of students being cognitively engaged. Students tended to ask, critique, help, and convince each other. We observed students engaged in group work for long periods of time. They stayed on task while collecting and interpreting data, writing conclusions, and suggesting ideas to each other.

Attitudes. Ms. McGee respected her students and rarely raised her voice in class. As in Ms. Anderson's class, the students addressed the teacher with respect and in a friendly manner. Ms. McGee allowed them to speak with their friends and to move around the class. When she went into recitation, she waited for a few seconds until the class calmed down. Although occasionally the class was noisy and the students were active in their working stations, they always calmed down in a few seconds and let her continue.

\section{Summary and Conclusions}

Teachers experience many challenges when teaching in urban settings. Inadequate resources, large class sizes, frequent movement of students in and out of classrooms, a high proportion of poor students, and low achievements are some characteristics of urban school settings that compound the challenges that teachers face (Barton \& Tobin, 2001; Bouillion \& Gomez, 2001; Lynch, 2000; Spillane, Diamond, Walker, Halverson, \& Jita, 2001; Tobin et al., 2001). The case studies reported here illustrate 2 teachers who have overcome many of these challenges and illustrates what makes good science teaching in urban middle schools.

The practices of these 2 teachers empowered their students to engage in inquiry-based instructions and learn challenging and important science content. Considering that inquiry-based instruction is complex even in the best of situations and that classrooms in which students engage in standard-based inquiry are rare (Crawford, 1999; Gallagher, 1989; Marx et al., 1994), the teaching of Ms. Anderson and Ms. McGee, who managed to carry out classroom and small-group discussions as well as technology-based inquiry, demonstrates what can be done by dedicated, concerned, and skillful teachers.

Our study shows that various aspects affect a teacher's ability to mediate inquiry in urban school classrooms. Basic management skills are essential for teaching anywhere, and managing the classroom is an essential constitute of pedagogical knowledge (Shulman, 1986). Nevertheless, in urban classrooms, management difficulties are very common and quite often interfere with teachers' ability to carry out innovative teaching approaches. Observations of other urban classrooms with management difficulties indicated that the classroom management that Ms. Anderson and Ms. McGee maintained is an essential prerequisite to creating an environment in which students learn.

Our analyses align with scholars who have stated that positive and encouraging attitudes of the teacher contribute substantially to the students' tendency to be involved, do excellent work, and attend to class activities (Atwater, 2000; Foster, 1997; Shulman, 1986). Both Atwater (2000) and Lynch (2000) addressed the issue of teachers' attitude. They claimed that a strong connection between teachers' supportive attitude and devotion to the goal of working in urban schools with a 
diverse student population and students' achievements. Our findings show that both Ms. McGee and Ms. Anderson expected a lot from their students. Ms. Anderson repeated her expectation daily in the poem she and the students read aloud together. Ms. McGee demonstrated her expectations by pressing students to understand, in challenging them by not providing answers for their questions, and by encouraging them to critique each other and her. They pressed their students to do thoughtful work, demanded high-quality products, and continuously probed the students to explain and give reasons for their work. Yet, both teachers respected their students.

Other scholars suggest using real-world context for teaching science (Krajcik et al., 1998; Marx et al., 1994; Solomon, 1993; Yager \& Tamir, 1993); however, it has an additional value when teaching science in urban settings (Atwater, 2000; Bouillion \& Gomez, 2001; Fusco, 2001). Using local, personal experiences is advocated by Banks (1998), who stated that to overcome the challenges urban schools face, we need to educate students so that they will have the knowledge, attitudes, and skills needed to help construct a public community in which all groups can and will participate. Teachers should help students compare community and cultural knowledge with school knowledge. The case studies of the 2 teachers presented here show them referring to community needs while teaching the curriculum. Ms. Anderson repeatedly used the air-quality driving question, referring to community health, and Ms. McGee provided many examples of accidents and hazards of driving in the city.

Suitable curriculum materials also play a major factor in enabling students to cognitively engage in inquiry. Our group developed learning materials that were enacted throughout the district. These learning materials focused on real-life contexts, used learning technologies to foster learning, and encouraged students to collaborate as part of learning in social context (Singer et al., 2000). Both Ms. Anderson and Ms. McGee managed to complete the projects, giving students many opportunities to learn the science ideas. One reason why they were able to complete the projects was because both teachers were always well prepared for class.

Teacher subject-matter knowledge also plays a key component in student learning (Shulman, 1986; Tamir, 1992, 1998). Both teachers demonstrated adequate knowledge of the content. In addition to content knowledge, different aspects of PCK appear relevant in doing inquiry-based science (Crawford, 1999). Ms. Anderson and Ms. McGee both demonstrated different strengths in PCK. Ms. Anderson monitored the students' work very carefully, paced them, modeled, and used analogies. Ms. McGee understood her students' difficulties. It was clear that she presses them to do thoughtful work and to develop higher order thinking skills by constant requests for reasoning. As Blumenfeld and colleagues (1997) and Putnam and Borko (1997) suggested, this might be the key point for teaching for understanding.

The instructional approaches encouraged in the curriculum materials require a significant departure from prevailing recitation and direct instruction to classroom teaching and align with those suggested by Haberman (1991) for good teaching in urban schools. As indicated earlier, both Ms. Anderson and Ms. McGee demonstrated many of these teaching practices. Drawing back to characteristics of good teaching in urban and other settings (Haberman, 1991; Schwartz, 1995; Stevens, 1996; Tate, 2001), we can conclude that both teachers:

- addressed big ideas and major concepts;

- planned what they were doing and helped their students do so;

- consistently treated their students with respect and applied ideas of fairness and equity in their classes;

- conducted investigations and helped the students to generate and interpret data;

- made the students work in heterogeneous groups;

- related new ideas to previously presented ones, especially to the driving question and to their previous investigations; 
- requested that students present their work to the whole class and revise these final presentations;

- used technology, throughout the unit, for various purposes such as learning about structure of matter, doing investigations, collecting data, and building models;

- allocated enough time for their students' learning;

- managed the complex teaching system required for effective PBS learning;

- provided various opportunities for learning meaningful ideas, in meaningful ways; and

- addressed individual differences and needs of their students.

Teachers face many challenges in teaching science and doing inquiry in urban schools. It is clear that providing relevant learning materials, technologies, and classroom support is not enough. In addition, providing teachers with knowledge of the subject matter, separated from relevant PCK, does not contribute to accomplishing the expected change in teaching practices in general and for urban schools in particular (Clermont, Krajcik, \& Borko, 1993). Both sufficient content knowledge and PCK appear to be important. The effective work of teachers described here can serve as case models for good teaching and reveals some important insights into teaching in urban settings that would allow us to plan professional development and teacher education better to benefit all our teachers.

\section{Research Limitations and Further Study}

Although in this study we avoided comparing the 2 exemplary teachers with other teachers who exhibited poor or mediocre skills, we believe that the readers, especially the ones who are acquainted with urban schools, could use best-cases examples better in planning their intervention programs. Further research could follow the teachers across time. Although urban schools face a high turnover rate for both students and teachers, Ms. Anderson has continued to work in the project. One potential and beneficial follow-up study could compare her recent teaching with the one described here to learn how her teaching and her students' scores have changed across time. Although this study aimed at following up 2 successful teachers, 1 of them does not teach in our projects anymore. Although more data on the work of these teachers in following years would allow us to better understand their performance in more advanced stages of the project, this could not happen. Although we know that 1 of the teachers got much more experience, and she even guides new teachers in teachers' professional-development meetings, we could not collect data on both teachers in a longitudinal study. Other work occurring in our research group explores the relationship of teaching and learning during the enactment of a middle-school chemistry unit. The work examines the enactments of urban middle-school science classrooms to see how the learning opportunities contribute to students meeting the learning goals of the unit (Harris, 2005; McNeill $\&$ Lizotte, 2005). Such work, like the work reported in this article, provides the field with valuable information on how reform-based materials and associated teaching practices support student understanding of important learning goals.

\section{Notes}

The research reported in this article was supported, in part, by the Center for Learning Technologies in Urban Schools (NSF Grant REC 0830310 A605), the Detroit Urban Systemic Initiative (NSF Grant ESR-9908234), and the Center for Curriculum Materials in Science (NSF Grant ESI-0227557). Any opinions expressed in this work are those of the authors and do not necessarily represent those of the funding agency or the University of Michigan. We also would 
like to thank the 2 teachers discussed in this article for their dedication and concern for improving how children in urban schools learn science.

\section{References}

American Association for the Advancement of Science. (2000). Middle Grades Science Textbooks Report. http://www.project2061.org/newsinfo/press/r1092899.htm

Anderson, C.W. (2001). Systemic reform, inquiry, and personal sense-making. Journal of Research in Science Teaching, 38, 629-630.

Atwater, M.M. (2000). Equity for Black Americans in precollege science. Science Education, 84, 154-179.

Ball, D. (2000). Bridging practices: Intertwining content and pedagogy in teaching and learning to teach. Journal of Teacher Education, 51, 241-247.

Banks, J.A. (1998). The lives and values of researchers: Implications for educating citizens in a multicultural society. Educational Researcher, 27, 4-17.

Barton, A.C. (1998). Margin and center: Intersections of homeless children, science education, and a pedagogy of liberation. Theory into Practice, 37, 296-305.

Barton, A.C. \& Tobin, K. (2001). Urban science education. Journal of Research in Science Teaching, 38, 843-846.

Blumenfeld, P.C. (1992). The task and the teacher: Enhancing student thoughtfulness in science. Advances in Research on Teaching, 3, 81-114.

Blumenfeld, P., Fishman, B., Krajcik, J., Marx, R., \& Solloway, E. (2000). Creating usable innovations in systemic reform: Scaling-up technology-embeded project-based science in urban schools. Educational Psychologist, 35, 149-164.

Blumenfeld, P.C., Marx, R.W., Patrick, H., \& Krajcik, J.S. (1998). Teaching for understanding. In B.J. Biddle, T.L. Good, \& I.F. Goodson (Eds.), International handbook of teachers and teaching (pp. 819-878). Dordrecht, The Netherlands: Kluwer.

Blumenfeld, P.C., Marx, R.W., Patrick, H., Soloway, E., \& Krajcik, J.S. (1997). Teaching for understanding. In B.J. Biddle, T.L. Good, \& I.F. Goodson (Eds.), The international handbooks of teachers and teaching (pp. 819-878). Dordrecht, The Netherlands: Kluwer.

Bouillion, L.M. \& Gomez, L.M. (2001). Connecting school and community with science learning: Real world problems and school-community partnerships as contextual scaffolds. Journal of Research in Science Teaching, 38, 878-898.

Brown, A.L. \& Campione, J.C. (1990). Communities of learning and thinking, or a context by any other name. In D. Kuhn (Ed.), Developmental perspectives on teaching and learning thinking skills (pp. 108-126). Basel, Switzerland: Karger.

Bybee, R.Y. (1993). Reforming science education, social perspectives and personal reflections. New York: Teachers College Press.

Clermont, C.P., Krajcik, J.S., \& Borko, H. (1993). The influence of an intensive in-service workshop on pedagogical content knowledge growth among novice chemical demonstrators. Journal of Research in Science Teaching, 30, 21-43.

Cochran, K.F. \& Jones, L.L. (1998). The subject matter knowledge of preservice science teachers. In B.J. Fraser \& K.G. Tobin (Eds.), International handbook of science education (pp. 707-718). Dordrecht, The Netherlands: Kluwer.

Cohen, D.K. \& Spillane, J.P. (1993). Policy and practice: The relations between governanace and instruction. In S.H. Fuhrman (Ed.), Designing coherent education policy (pp. 35-95). San Francisco: Jossey-Bass. 
Crawford, B.A. (1999). Is it realistic to expect a preservice teacher to create an inquiry-based classroom? Journal of Science Teacher Education, 10, 175-194.

Edelson, D.C. (2001). Learning-for-use: A framework for the design of technology-supported inquiry activities. Journal of Research in Science Teaching, 38, 355-385.

Fishman, B. \& Davis, E.A. (in press). Teacher learning research and the learning sciences. In R.K. Sawyer (Ed.), The Cambridge handbook of the learning sciences. New York: Cambridge University Press.

Fishman, B., Marx, R.W., Best, S., \& Tal, R.T. (2003). A design approach to professional development: Linking teacher and student learning in systemic reform. Teaching and Teacher Education, 19, 643-658.

Foster, M. (1997). Black teachers on teaching. New York: New Press.

Fusco, D. (2001). Creating relevant science through urban planning and gardening. Journal of Research in Science Teaching, 38, 860-877.

Gallagher, J.J. (1989). Research on secondary school science practices, knowledge and beliefs: A basis for restructuring. In M. Matyas, K. Tobin, \& B. Fraser (Eds.), Looking into windows: Qualitative research in science education. Washington, DC: American Association for the Advancement of Science.

Gallagher, J.J. (1991). Uses of Interpretive Research in Science Education. In J.J. Gallagher (Ed.), Interpretive research in science education (pp. 3-17). NARST Monograph No. 4.

Guba, E.G. \& Lincoln, Y.S. (1985). Naturalistic inquiry. Beverly Hills, CA: Sage.

Haberman, M. (1991). The pedagogy of poverty versus good teaching. Phi Delta Kappan, 73, 290-294.

Harris, C.J. (2005, April). Opportunities for standards-based science learning. Paper presented at the annual meeting of the American Educational Research Association, Montreal.

Hewson, P.W., Kahle, J.B., Scantlebury, K., \& Davies, D. (2001). Equitable science education in urban middle schools: Do reform efforts make a difference? Journal of Research in Science Teaching, 38, 1130-1144.

Jackson, S., Krajcik, J., \& Soloway, E. (2000). Model-it: A design retrospective. In M. Jacobson \& R. Kozma (Eds.), Advanced designs for the technologies of learning: Innovations in science and mathematics education (pp. 77-116). Hillsdale, NJ: Erlbaum.

Janesick, V.J. (2000). The choreography of qualitative research design. In N.K. Denzin \& Y.S. Lincoln (Eds.), Handbook of qualitative research (2nd ed., pp. 379-399). Thousand Oaks: Sage.

Kahle, J.B. (1997). Systemic reform: Challenges and changes. Science Educator, 6, 1-6.

Kahle, J.B., Meece, J., \& Scantlebury, K. (2000). Urban African-American middle school science students: Does standards-based teaching make a difference? Journal of Research in Science Teaching, 37, 1019-1041.

Kesidou, S. \& Roseman, J.E. (2002). How well do middle school science programs measure up? Findings from Project 2061's curriculum review. Journal of Research in Science Teaching, 39, $522-549$.

Keys, C.W. \& Bryan, L.A. (2001). Co-constructing inquiry based science with teachers: Essential research for lasting reform. Journal of Research in Science Teaching, 38, 631-645.

Krajcik, J., Blumenfeld, P.C., Marx, R.W., Bass, K.M., \& Fredricks, J. (1998). Inquiry in project-based science classrooms: Initial attempts by middle school students. Journal of the Learning Sciences, 7, 313-350.

Krajcik, J., Blumenfeld, P., Marx, R., \& Solloway, E. (1994). A collaborative model for helping middle grade teachers learn project-based instruction. The Elementary Science Journal, 94, 483-498. 
Krajcik, J. \& Starr, M. (2001). Learning science content in a project-based environment. In R. Tinker \& J.S. Krajcik (Eds.), Portable technologies: Science learning in context (pp. 103-119). Dordrecht, The Netherlands: Kluwer.

Ladewski, B.G., Krajcik, J.S., \& Harvey, C.L. (1994). A middle grade science teacher's emerging understanding of project-based instruction. The Elementary School Journal, 94, 499515.

Lynch, S.J. (2000). Equity and science education reform. Mahwah, NJ: Erlbaum.

Lynch, S., Atwater, M., Cawley, J., Eccles, J., Lee, O., Marrett, C., Rojas-Medlin, D., Secada, W., Stephanich, G., \& Willetto, A. (1996). An equity blueprint for Project 2061 science education reform (2nd draft). Washington, DC: American Association for the Advancementof Science.

Magnusson, S., Krajcik, J., \& Borko, H. (1999). Nature, sources and develpoment of pedagogical content knowledge for science teaching. In N. Lederman \& J. Guess-Newsome (Eds.), Examining pedagogical content knowledge (pp. 95-132). Dordrecht, The Nederlands: Kluwer.

Marx, R., Blumenfeld, P., Krajcik, J., Blunk, M., Crawford, B., Kelly, B., \& Meyer, K. (1994). Encating project-based science: Experiences of four middle grade teachers. The Elementary School Journal, 94, 517-538.

Marx, R.W., Blumenfeld, P.C., Krajcik, J.S., Fishman, B., Solloway, E., Geier, R., \& Tal, R.T. (2004). Inquiry-based science in the middle grades: Assessment of learning in urban systemic reform. Journal of Research in Science Teaching, 41, 1063-1080.

Marx, R.W., Blumenfeld, P.C., Krajcik, J.S., \& Soloway, E. (1998). New technologies for teacher professional development. Teaching and Teacher Education, 14, 33-52.

May, W.T., Lantz, T., \& Rackliffe, G. (1993). Good teachers making the best of it: Case studies of elementary art and music teaching. Center for the Learning and Teaching of Elementary Subjects. Michigan State University. Eric Document Reproduction Service No. ED 360230.

McNeill, K.L. \& Lizotte, D.J. (2005, April). Identifying teacher practices that support students' explanation in science. Paper presented at the annual meeting of the American Educational Research Association, Montreal.

Minstrell, J. \& van Zee, E. (2000). Inquiring into inquiry learning and teaching in science. Washington, DC: American Association for the Advancement of Science.

Novak, A. \& Gleason, C. (2001). Incorporating portable technology to enhance an inquiry, project-based middle school science classroom. In R. Tinker \& J.S. Krajcik (Eds.), Portable technologies: Science learning in context (pp. 29-69). Dordrecht, The Netherlands: Kluwer.

O’Day, J. \& Smith, M. (1993). Systemic reforms and educational opportunity. In S. Furhrman (Ed.), Designing coherent educational policy: Improving the system (pp. 250-312). San Fransisco: Jossey-Bass.

Patton, M.Q. (1990). Qualitative evaluation and research methods. Newbury Park, CA: Sage.

Putnam, R.T. \& Borko, H. (1997). Teacher learning: Implications of new views of cognition. In B.J. Biddle, T.L. Good, \& I.F. Goodson (Eds.), International handbook of teachers and teaching (pp. 1223-1296). Dordrecht, The Netherlands: Kluwer.

Rodriguez, A.J. (2001). From gap gazing to promissing cases: Moving toward equity in urban education. Journal of Research in Science Teaching, 38, 1115-1129.

Schwandt, T.A. (1994). Constructivist, interpretivist, approaches to human inquiry. In N.K. Denzin \& Y.S. Lincoln (Eds.), Handbook of qualitataive research (pp. 118-137). London: Sage.

Schwartz, W. (1995). Opportunity to learn standards: their impact on urban students. Eric/Cue Digest, 110. 
Shulman, L. (1986). Those who understand: Knowledge growth in teaching. Educational Researcher, 15, 4-14.

Singer, J., Marx, R.W., Krajcik, J., \& Clay Chambers, J. (2000). Constructing extended inquiry projects: Curriculum materials for science education reform. Educational Psychologist, $35,165-178$.

Singer, J., Tal, R.T., \& Wu, H.-K. (2003). Using multiple representations to support urban middle school students' understanding of particular nature of matter. School Science and Mathematics, 103, 28-45.

Solomon, J. (1993). Teaching science, technology and society. Philadelphia: Open University Press.

Spillane, J.P., Diamond, J.B., Walker, L.J., Halverson, R., \& Jita, L. (2001). Urban school leadership in elementary science instruction: Identifying and activating resources in an undervalued school subject. Journal of Research in Science Teaching, 38, 918-940.

St. John, M. \& Pratt, H. (1997). The factors that contribute to the 'best cases' of standardsbased reform. School Science \& Mathematics, 97, 316-324.

Stern, L. \& Roseman, J.-E. (2000, April-May). Can middle-school science textbooks help students learn important ideas? Findings from Project 2061 curriculum evaluation study: Life science. Paper presented at the annual meeting of the National Association for Research in Science Teaching, New Orleans, LA.

Stevens, F. (1996, April). The need to expand the opportunity to learn conceptual framework: Should students, parents and school resources be included? Paper presented at the annual meeting of AREA, New York.

Taines, C., Schneider, R., \& Blumenfeld, P. (2000, April). Observations of urban middle school students engaged in technology-supported inquiry. Paper presented at the annual meeting of AERA, New Orleans, LA.

Tamir, P. (1992). High school biology teachers' image of subject matter: An exploratory study. American Biology Teacher, 54, 212-217.

Tamir, P. (1998). Assessment and evaluation in science education: Opportunities to learn and outcomes. In B. Fraser \& K. Tobin (Eds.), International handbook of research in science education (pp. 761-790). Dordrecht, The Netherlands: Kluwer.

Tate, W. (2001). Science education as a civil right: Urban schools and opportunity-to-learn considerations. Journal of Research in Science Teaching, 38, 1015-1028.

Tobin, K., Roth, W.-M., \& Zimmermann, A. (2001). Learning to teach science in urban schools. Journal of Research in Science Teaching, 38, 941-964.

Tobin, K., Seiler, G., \& Walls, E. (1999). Reproduction of social class in the teaching and learning of science in urban high schools. Research in Science Education, 29, 171-187.

Van Driel, J.H., Beijaard, D., \& Verloop, N. (2001). Professional development and reform in science education: The role of teachers' practical knowledge. Journal of Research in Science Teaching, 38, 137-158.

van Es, E., Reiser, B.J., Matese, G., \& Gomez, L.M. (2002, April-May). Supporting teachers in enacting inquiry-based curricula. Paper presented at the annual meeting of the American Educational Research Association, New Orleans, LA.

Weiner, L.B. (1999). To teach or not to teach in an urban school? The English Journal, 88, 21-25.

Yager, R.E. \& Tamir, P. (1993). STS approach: Reasons, accomplishments, and outcomes. Science Education, 77, 637-658. 